\section{Four decades of forest succession in the oak-dominated forest reserves in Slovakia}

\author{
Milan Saniga, Miroslav Balanda, Stanislav Kucbel, Ján Pittner
}

Species composition, production and the recovery processes were analyzed in three protected areas dominated by natural oak forests in Slovakia over four decades after the cessation of human impact. In each forest reserve, three permanent plots of $\mathbf{0 . 5}$ ha were established and monitored regularly every 10 years. As expected, a decrease of oaks in all investigated areas was observed, regardless of the intensity of past human interventions. Growth rates of oak stem density were negative in all sites ranging from $-0.7 \% \mathrm{yr}^{-1}$ (Kašivárová) to $-2.1 \% \mathrm{yr}^{-1}$ (Bujanov). A typical rotated-sigmoid distribution of tree diameters was detected over the whole period only for the Boky reserve, while the moderately affected site (Kašivárová) showed a bimodal pattern and the most affected site (Bujanov) showed the typical unimodal distribution. Considering the spatial diversity, such evidence is consistent with the different intensity of past human impacts occurred at each site. In Boky, the most diverse structure was reflected in the highest long-term mean stem density and the lowest basal area and growing stock. The past-affected sites reached higher values of basic stand parameters, with the average basal area and the growing stock correlated negatively with the level of structural heterogeneity. A constant increase of deadwood volume and dead-to-live wood ratio was also observed over the whole period of investigation. Long-term volume of deadwood and its proportion tended to be higher in the reserves formerly affected by human inteventions. A tendency towards a rotated-sigmoid distribution of diameters was detected for both sites that experienced past human impacts. Considering the vertical stand structure, the most dynamic changes were observed in the lower and middle layer. Moreover, the displacement of the light-demanding oaks by shade-tolerant species (beech, hornbeam) was detected. The intensity of such substitution directly reflected the intensity of structure modification in the past. Our results suggest that the process of forest recovery and oak loss significantly depends on the level of past human interventions.

Keywords: Oak Decline, Past Human Impact, Recovery, Forest Reserve, Quercus petraea L.

\section{Introduction}

Well preserved old-growth oak forests are quite rare in Europe and are mostly dominated by pedunculate oak (Quercus robur L. Korpel 1989, 1995, Smejkal et al. 1995, Parviainen et al. 1999). Natural mixed sessile oak (Quercus petraea L.) forests, as they are easily accessible and have been intensively used in the past (Kavuljak 1942, Korpel 1995, Smejkal et al. 1995), have remained untouched only in a very small area. In the western Carpathians, the remnants of oldgrowth mixed $Q$. petraea forests occur at in-

termediate and low altitudes (Blattný \& Štastný 1959).

Since the second half of the $20^{\text {th }}$ century, many researchers from almost all European countries have investigated the symptoms and course of oak decline (e.g., Oleksyn \& Przybyl 1987, Hartmann et al. 1989, Ragazzi et al. 1989, Siwecki \& Liese 1991, Thomas et al. 2002). The main goal of these studies was to identify crucial factors and the trigger mechanism of such phenomenon. In most cases, oak dieback was studied in large areas regardless of stand origin. However, in addi-

Technical University in Zvolen, T. G. Masaryka 24, SK 960-53 Zvolen (Slovak Republic)

@ Miroslav Balanda (miroslav.balanda@tuzvo.sk)

Received: Mar 22, 2013 - Accepted: Feb 03, 2014

Citation: Saniga M, Balanda M, Kucbel S, Pittner J, 2014. Four decades of forest succession in the oak-dominated forest reserves in Slovakia. iForest 7: 324-332 [online 2014-04-17] URL: http://www.sisef.it/iforest/contents/?id=ifor0996-007

Communicated by: Emanuele Lingua tion to the long-term monitoring, it is necessary to incorporate also the historical background, when the structure and development of recent natural forests are analyzed. Such approach may allow the identification of underlying factors that caused vegetation changes (Josefsson et al. 2009).

The origin and the future development of oak forests have been widely discussed, leading to several opposing theories. According to the classic high-forest theory (Watt 1925, Whitmore 1975, Leibundgut 1993, Korpel 1995, Birks 2005), the oak-dominated climax (equilibrium) structure is the final step of a successional process and represents a stable adaptation to local environmental conditions (Bohn \& Neuhäusl 2000, Halamová \& Saniga 2006). Tree species composition could be temporarily modified by a smallscale canopy disturbance, but the ecosystem will immediately return to the equilibrium by its own self-regulation processes.

On the other hand, the disturbance theory (Connell 1978, White \& Pickett 1985, Oliver \& Larson 1996) attributes the dominance of light-demanding oak to the impact of mid- to large-scale disturbances. It considers the oak-dominated forest to be the mid-stage of a continuous, but constantly ingressive process of forest succession leading to the final dominance of shade-tolerant species.

According to a third group of theories, the recent extent of oak-dominated forests in the temperate zone is most probably the result of the past human exploitation in favor of oak (for charcoal and fuelwood production, cattle pasture) or the impact of large herbivors (Vera 2000).

Evidence from several recent studies support the last mentioned explanation. Based on 50-years monitoring of forest reserves, Brang et al. (2011) and Rohner et al. (2012) described a trend towards the reduction of species richness in Switzerland lowland forests. The light-demanding species promoted by former human intervention were increasingly shaded out after the cessation of forest management. Petritan et al. (2012) provided a complex study of the stand structure of natural mixed Q. petraea forest in Runcu-Grosi (Romania). They conditioned the preservation of recent proportion of oak by the occurrence of either major canopy disturbance or silvicultural intervention. However, Cowell et al. (2010) pointed at the minor role of canopy gaps in the development of oak-mixed forest remnants in Dobbs Natural Area (Indiana, USA) and outlined the parallel between the current species composition and historical shift in the light regime due to grazing. Similarly, Matuszkiewicz (1977), Jakubowska-Gabara (1996) and Hédl et al. (2010) argue for the abandonment of forest exploitation and pasture as the main driving factor of the secondary succession of ther- 
mophilous oak communities towards the mesic forests.

This study focuses on the spatial analysis of natural succession and structural change of oak-dominated forests affected by different intensity of human impacts in the past. In particular, we tried to address the following questions:

- Does the nature and intensity of oak decline differ depending upon the intensity of former human impacts on the stand or is it a common phenomenon of recent times?

- Can the forest naturalness be inferred from the current distribution of tree diameters through its fitting to the rotated sigmoid function? How could a shift in diameter distribution in a time span of four decades reflect the intensity of past interventions?

- Can structural changes be traced in the vertical structure of the investigated forests?

\section{Material and methods}

Model protected areas under different ex ploitation regimes in the past were chosen in the western Carpathians of Slovakia according to the following criteria:

- a minimum area of the forest remnant (protected area) of 50 ha to secure the conditions for self-development (according to Bücking 2003);

- a proportion of oak by stand basal area of at least $90 \%$ in the first inventory;

- at least three decades covered by forest inventory campaigns;

- historical records describing the exploitation intensity in the past.

Three National Nature Reserves (NNR) met the above criteria:

1. The NNR Boky, characterized by the lowest degree of hemeroby (sensu Hill et al. 2002); an old-growth (pristine) forest, with no-known human impact. The site is inaccessible, and no exploitation has been recorded on historical sources.

2. The NNR Kašivárová, a natural forest (sensu Schuck et al. 1994) located in an area where traces of past human impacts are still detectable (some scattered beech and oak individuals were harvested to produce charcoal).

Tab. 1 - Main environmental characteristics of the three localities selected for this study.

\begin{tabular}{lccc}
\hline \multirow{2}{*}{ Characteristics } & \multicolumn{3}{c}{ Forest reserve } \\
\cline { 2 - 4 } & Kašivárová & Boky & Bujanov \\
\hline Latitude $\left[{ }^{\circ} \mathrm{N}\right]$ & $48^{\circ} 27^{\prime} 59^{\prime} 8^{\circ}$ & $48^{\circ} 33^{\prime} 59^{\prime \prime}$ & $48^{\circ} 52^{\prime} 19^{\prime \prime}$ \\
Longitude [ $\left.{ }^{\circ} \mathrm{E}\right]$ & $18^{\circ} 46^{\prime} 28^{\prime \prime}$ & $19^{\circ} 01^{\prime} 22^{\prime \prime}$ & $21^{\circ} 03^{\prime} 38^{\prime \prime}$ \\
Years of measurement & $1966,1976,1986$, & $1974,1984,1994$, & 1966,2009 \\
& 1996,2011 & 2004 & \\
Altitude [m a.s.l] & $280-590$ & $480-600$ & $420-760$ \\
Bedrock & andesite & andesite & granite \\
Soil type & eutric cambisol & eutric cambisol & dystric cambisol \\
Mean temperature [ $\left.{ }^{\circ} \mathrm{C}\right]$ & $8.0-8.2$ & 7.5 & $7.0-7.2$ \\
Mean precipitation [mm] & 750 & 720 & 675 \\
Area of forest reserve [ha] & 49.8 & 176.5 & 88.2 \\
Forest plant community & Carpinion betuli & Carpinion betuli & Carpinion betuli \\
\hline
\end{tabular}

Volume of each tree was calculated according to the two-parameter (dbh and height) equations derived by Petráš \& Pajtík (1991). For the determination of the volume of broken standing deadwood Huber's formula was used (Šmelko 2000 - eqn. 1):

$$
v=\frac{\pi}{4} d_{1 / 2}^{2} h_{s}
$$
ted area in 1964.

The three reserves have been strictly protected since 1930 (Kašivárová) or 1964 (Bujanov and Boky). The sites are located in the beech-oak altitudinal zone (Tab. 1) and belong to the alliance Carpinion betuli (Jarolímek \& Šibík 2008). Parent materials include andesite and granite, the prevailing soil type is cambisol. The mean annual temperature ranges from 7.0 to $8.2{ }^{\circ} \mathrm{C}$ and the annual precipitation from $675 \mathrm{~mm}$ (Bujanov) to 750 mm (Kašivárová).

The dataset analyzed has originated from a 45-years (30-years in Boky) long-term research on permanent plots representing various developmental stages of selected oakdominated forests (Korpel 1995). The outcomes of previous studies on the same data were published by Korpel (1995), Halamová \& Saniga (2006), Saniga (2005), Tomaštík \& Saniga (2011).

In each reserve, three 0.5 ha plots were established. On each plot, all living trees, standing deadwood (snags) and lying deadwood (logs) were recorded. The lower size limit for standing stems was a diameter at breast height $(\mathrm{dbh})$ of $4 \mathrm{~cm}$. As for downed deadwood, all logs or log parts with a largeend diameter $\geq 8 \mathrm{~cm}$ were recorded. For each standing tree, we recorded species, dbh, height and status (living or dead). Tree species, small- and large-end diameter and total length were measured for the logs.

Dominant height $\left(h_{10 \%}\right)$ was computed for each site as the mean height of the $10 \%$ tallest trees (Šmelko 2000), and was used to assign each tree to one of three tree layers (lower, middle and upper layer) using the following thresholds: (i) lower layer (trees with height $h<1 / 3 h_{10 \%}$ ); (ii) middle layer $\left(1 / 3 h_{10 \%} \leq h<2 / 3 h_{10 \%}\right)$; and (iii) upper layer $h \geq 2 / 3 h_{10 \%}$.

where $d_{1 / 2}$ is the mid-height diameter and $h_{\mathrm{s}}$ is the height of the broken snag. The midheight diameter was calculated by linear interpolation using the snag dbh and the respective tree height from the stand height curve.

The downed deadwood volume was computed by Smalian's formula (Šmelko 2000 eqn. 2):

$$
v=\frac{\pi}{4} \cdot \frac{d_{s}^{2}+d_{L}^{2}}{2} \cdot l
$$

where $d_{\mathrm{S}}$ is the small-end diameter, $d_{\mathrm{L}}$ the large-end diameter, and $l$ is the log length.

The diameter structure was analysed by fitting either the negative exponential function, the single Weibull function (three-parameter form), or the finite mixture of two Weibull functions (seven-parameter form) to the empirical diameter distributions. More information on the functions used can be found in Westphal et al. (2006) and Zhang et al. (2001). The goodness-of-fit was examined using the likelihood-ratio $\chi^{2}$ test. All calculations were performed using the "mixdist" package of $\mathrm{R}$ software (Macdonald \& $\mathrm{Du}$ 2010, R Development Core Team 2010).

Temporal changes in stem density and basal area were analyzed by assessing the population growth rates $(G R)$ according to Taylor et al. (2004). In each reserve, growth rates were calculated for oak and other tree species using the census data of the first and the last inventory. Moreover, the same calculation was performed for oak and other tree species in each stand layer (eqn. 3):

$$
G R=\frac{1}{t} \cdot\left(\frac{N_{t}-N_{0}}{N_{0}}\right) \cdot 100
$$

where $N_{t}$ is the stem density (or basal area) at the time of the last inventory, $N_{0}$ the stem density (or basal area) at the time of the first inventory, and $t$ the census interval. Differences among the population growth rate values obtained were tested using the Kruskal-Wallis test $(\alpha=0.05)$.

\section{Results}

Over the whole studied period, the most differentiated structure was observed in the reserve with no past human impact (Boky). Differentiated structure was reflected in the highest long-term mean stem density $(890 \pm$ $151 \mathrm{ha}^{-1}$ ) and the lowest basal area and growing stock in this site $\left(36.5 \pm 1.4 \mathrm{~m}^{2} \mathrm{ha}^{-1}\right.$ and $284 \pm 22 \mathrm{~m}^{3}$ ha $^{-1}$, respectively - Tab. 2). 
Tab. 2 - Basic stand characteristics (living trees of $\mathrm{dbh}>4 \mathrm{~cm}$ ) in the investigated forest reserves.

\begin{tabular}{|c|c|c|c|c|c|c|c|c|c|c|}
\hline \multirow{2}{*}{ Parameter } & \multicolumn{2}{|l|}{ Reserve/ } & \multicolumn{2}{|l|}{ Boky } & \multicolumn{3}{|c|}{ Kašivárová } & \multicolumn{3}{|c|}{ Bujanov } \\
\hline & Decade & Together & Oak & $\%$ & Together & Oak & $\%$ & Together & Oak & $\%$ \\
\hline Stem & $1960 \mathrm{~s}$ & - & - & - & $284 \pm 54$ & $239 \pm 33$ & $84 \pm 10$ & $414 \pm 77$ & $381 \pm 75$ & $92 \pm 1$ \\
\hline density & $1970 \mathrm{~s}$ & $1068 \pm 158$ & $945 \pm 42$ & $89 \pm 9$ & $300 \pm 50$ & $239 \pm 41$ & $80 \pm 10$ & - & - & - \\
\hline \multirow{4}{*}{$\left(\mathrm{ha}^{-1}\right)$} & $1980 \mathrm{~s}$ & $921 \pm 90$ & $799 \pm 27$ & $87 \pm 11$ & $257 \pm 42$ & $227 \pm 30$ & $88 \pm 8$ & - & - & - \\
\hline & $1990 \mathrm{~s}$ & $867 \pm 120$ & $637 \pm 70$ & $74 \pm 18$ & $199 \pm 23$ & $183 \pm 27$ & $92 \pm 7$ & - & - & - \\
\hline & $2000 \mathrm{~s}$ & $703 \pm 68$ & $508 \pm 36$ & $72 \pm 6$ & $703 \pm 229$ & $163 \pm 52$ & $23 \pm 18$ & $482 \pm 69$ & $198 \pm 8$ & $41 \pm 5$ \\
\hline & Mean \pm SD & $890 \pm 151$ & $722 \pm 190$ & $80 \pm 8$ & $349 \pm 202$ & $210 \pm 35$ & $74 \pm 26$ & $448 \pm 48$ & $290 \pm 129$ & $67 \pm 26$ \\
\hline \multirow{6}{*}{$\begin{array}{l}\text { Basal area } \\
\left(\mathrm{m}^{2} \mathrm{ha}^{-1}\right)\end{array}$} & $1960 \mathrm{~s}$ & - & - & - & $43.1 \pm 2.1$ & $42.3 \pm 2.6$ & $98 \pm 1$ & $42.5 \pm 0.3$ & $41.9 \pm 0.5$ & $93 \pm 1$ \\
\hline & $1970 \mathrm{~s}$ & $35.1 \pm 5.3$ & $34.3 \pm 5.9$ & $98 \pm 3$ & $44.6 \pm 2.3$ & $43.3 \pm 2.4$ & $97 \pm 1$ & - & - & - \\
\hline & $1980 \mathrm{~s}$ & $38.1 \pm 4.3$ & $37.1 \pm 5.1$ & $97 \pm 1$ & $45.2 \pm 2.2$ & $44.5 \pm 2.5$ & $99 \pm 1$ & - & - & - \\
\hline & $1990 \mathrm{~s}$ & $37.2 \pm 3.9$ & $35.5 \pm 5.1$ & $95 \pm 5$ & $39.6 \pm 1.7$ & $39.2 \pm 1.9$ & $99 \pm 1$ & - & - & - \\
\hline & $2000 \mathrm{~s}$ & $35.5 \pm 12.5$ & $32.2 \pm 13.4$ & $90 \pm 4$ & $38.8 \pm 3.3$ & $32.0 \pm 3.2$ & $83 \pm 9$ & $45.4 \pm 3.7$ & $34.8 \pm 1.8$ & $77 \pm 4$ \\
\hline & Mean \pm SD & $36.5 \pm 1.4$ & $34.8 \pm 2.1$ & $95 \pm 3$ & $42.3 \pm 2.9$ & $40.3 \pm 5.0$ & $95 \pm 6$ & $44.0 \pm 2.1$ & $38.4 \pm 5.0$ & $88 \pm 8$ \\
\hline \multirow{6}{*}{$\begin{array}{l}\text { Growing } \\
\text { stock } \\
\left(\mathrm{m}^{3} \mathrm{ha}^{-1}\right)\end{array}$} & $1960 \mathrm{~s}$ & - & - & - & $467 \pm 83$ & $462 \pm 84$ & $99 \pm 1$ & $484 \pm 28$ & $479 \pm 30$ & $99 \pm 1$ \\
\hline & $1970 \mathrm{~s}$ & $254 \pm 58$ & $252 \pm 59$ & $99 \pm 1$ & $483 \pm 60$ & $474 \pm 60$ & $98 \pm 2$ & - & - & - \\
\hline & $1980 \mathrm{~s}$ & $307 \pm 56$ & $303 \pm 57$ & $99 \pm 2$ & $508 \pm 90$ & $503 \pm 92$ & $99 \pm 1$ & - & - & - \\
\hline & $1990 \mathrm{~s}$ & $292 \pm 47$ & $286 \pm 50$ & $98 \pm 3$ & $457 \pm 47$ & $454 \pm 46$ & $99 \pm 1$ & - & - & - \\
\hline & $2000 \mathrm{~s}$ & $281 \pm 132$ & $266 \pm 136$ & $94 \pm 3$ & $422 \pm 42$ & $381 \pm 44$ & $90 \pm 2$ & $553 \pm 37$ & $440 \pm 19$ & $80 \pm 2$ \\
\hline & Mean \pm SD & $284 \pm 22$ & $276 \pm 22$ & $97 \pm 2$ & $467 \pm 32$ & $455 \pm 45$ & $97 \pm 4$ & $518 \pm 49$ & $460 \pm 28$ & $89 \pm 10$ \\
\hline
\end{tabular}

Natural reserves with various levels of past human impact showed a more homogenous stand structure, as revealed by a significantly lower stem density and higher basal area and growing stock. In the forest most strongly affected in the past (Bujanov) the long-term mean of basal area was higher by $20 \%(44.0$ $\left.\pm 2.1 \mathrm{~m}^{2} \mathrm{ha}^{-1}\right)$ and that of growing stock by $83 \%\left(518 \pm 49 \mathrm{~m}^{3} \mathrm{ha}^{-1}\right)$ as compared with the Boky reserve. The long-term mean of deadwood volume (Tab. 3) in the site with past human impact (Kašivárová) was three times higher than in the old-growth forest in Boky. Similarly, the dead-to-live wood ratio in Kašivárová $(28.1 \pm 15.1 \%)$ was nearly twofold in comparison to the Boky reserve (15.0 $\pm 6.1 \%$ ). In both sites a gradual increase of deadwood volume as well as its proportion from growing stock was observed over the whole period of investigation.

Regarding the temporal changes of basic stand characteristics, except for continuous increase of deadwood volume, no significant trends were observed over the entire study period. However, since the mid-1980s we recorded a gradual decrease of basal area and growing stock in the Boky and Kašivárová reserves (a detailed analysis was not possible in Bujanov). Such decrease was was moderate in Boky and stronger in Kašivárová, according to the level of past human impacts on the forest (Fig. 1).

A continuous decline of oak stem density was recorded in all studied sites over the entire period of investigation. Moreover, since the 1980s a decrease of oak basal area and growing stock was also observed, yet much more intensive than that recorded for the whole stand (Fig. 1, Tab. 2). At the site with no past human interventions (Boky) the basal area of oak decreased from 37.1 to 32.2 $\mathrm{m}^{2} \mathrm{ha}^{-1}$, whereas oak decline was more rele- vant (from 44.5 to $32.0 \mathrm{~m}^{2} \mathrm{ha}^{-1}$ ) in the forest with past human impact (Kašivárová). At the same time, an increase of basal area and growing stock was recorded for the other tree species, especially over the last decade (Fig. 1). The above patterns were confirmed also at the research-plot level (see Fig. 2 for temporal changes in the stand parameters over the investigated period).

The starting species composition was very similar in all the investigated sites. At the time of the first inventory, oaks reached the highest proportion in terms of stem number or basal area (Fig. 3). The admixture of the other tree species varied among the studied sites. In Boky the admixture consisted of field maple (Acer campestre), hornbeam (Carpinus betulus) and wild service tree (Sorbus torminalis). In Kašivárová the most important additional tree species were beech (Fagus sylvatica) and hornbeam. In Bujanov the only additional tree species was beech.

The stand development over the census period led to a substantial shift in the tree species structure. Regardless of the interdecadal variation, the recorded structural changes resulted in a general decline of oak proportion in all studied reserves (Fig. 3). The decrease of oak proportion in stem num-

ber was smallest in Boky (from $89 \%$ to $72 \%$ ). The largest decrease over the 45 -years period was observed in Kašivárová, with a decline from $84 \%$ to $23 \%$, while the proportion of hornbeam expanded from $1 \%$ to $51 \%$. We also observed a significant increase of beech by $16 \%$ in this site. A similar change was recorded in Bujanov, where the share of oak decreased from $92 \%$ to $41 \%$ and the share of beech raised from $8 \%$ to $58 \%$. Considering the proportions in basal area, the changes in species composition were not so apparent. The recruitment of other tree species reflected in stem numbers has not yet affected significantly the total basal area and oak has kept its dominant position in all investigated reserves. The recorded decrease of oak proportion in basal area was highest in Bujanov, however, not exceeding 22\% (Fig. 3 ).

Diameter distributions observed at the beginning of the investigated period differed strongly among the studied reserves (Fig. 4). Unlike the old-growth forest Boky showing a typical rotated-sigmoid diameter distribution, diameter structures in Kašivárová and Bujanov showed bimodal patterns with a distinct dominance of the upper tree layer. However, over the studied period a conver-

Tab. 3 - Deadwood volume and its proportion from the growing stock for the investigated forest reserves.

\begin{tabular}{lcccccc}
\hline \multirow{2}{*}{ Years } & \multicolumn{6}{c}{ Forest reserve } \\
\cline { 2 - 7 } & Boky & Kašivárová & Bujanov & Boky & Kašivárová & Bujanov \\
\cline { 2 - 7 } & \multicolumn{2}{c}{ Deadwood volume $\left(\mathbf{m}^{\mathbf{3}} \mathbf{h a}^{-1}\right)$} & \multicolumn{2}{c}{ Dead-to-live wood ratio (\%) } \\
\hline $1960 \mathrm{~s}$ & - & $47 \pm 18$ & - & - & $10 \pm 3$ & - \\
$1970 \mathrm{~s}$ & $17 \pm 15$ & $86 \pm 28$ & - & $7 \pm 6$ & $18 \pm 3$ & - \\
$1980 \mathrm{~s}$ & $38 \pm 19$ & $107 \pm 35$ & - & $12 \pm 4$ & $21 \pm 5$ & - \\
$1990 \mathrm{~s}$ & $52 \pm 19$ & $188 \pm 36$ & - & $18 \pm 9$ & $41 \pm 7$ & - \\
$2000 \mathrm{~s}$ & $65 \pm 25$ & $212 \pm 59$ & $91 \pm 60$ & $23 \pm 10$ & $50 \pm 16$ & $17 \pm 9$ \\
Mean $\pm \mathrm{SD}$ & $43 \pm 21$ & $128 \pm 70$ & - & $15 \pm 6$ & $28 \pm 15$ & - \\
\hline
\end{tabular}



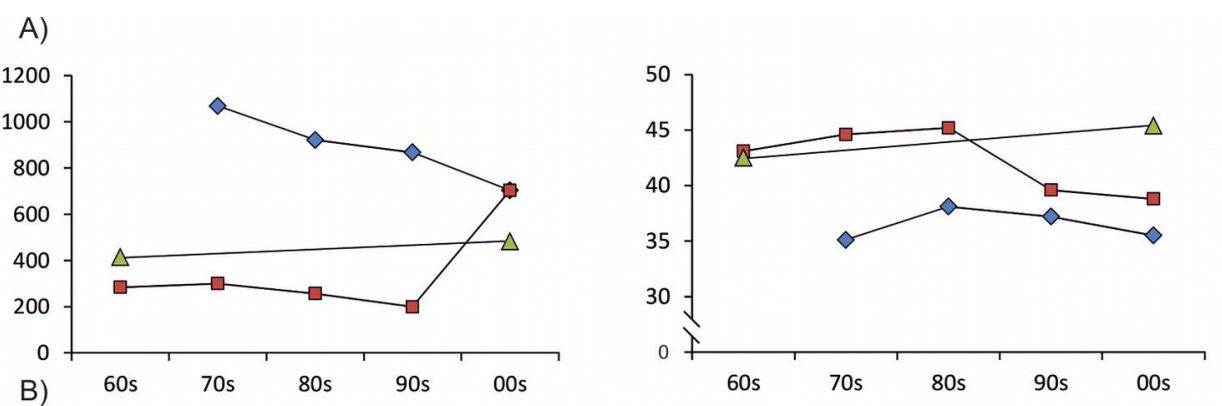

Fig. 1 - Temporal development of stem density and basal area in the investigated forest reserves. (A): all tree species; (B): oaks; (C): other species.
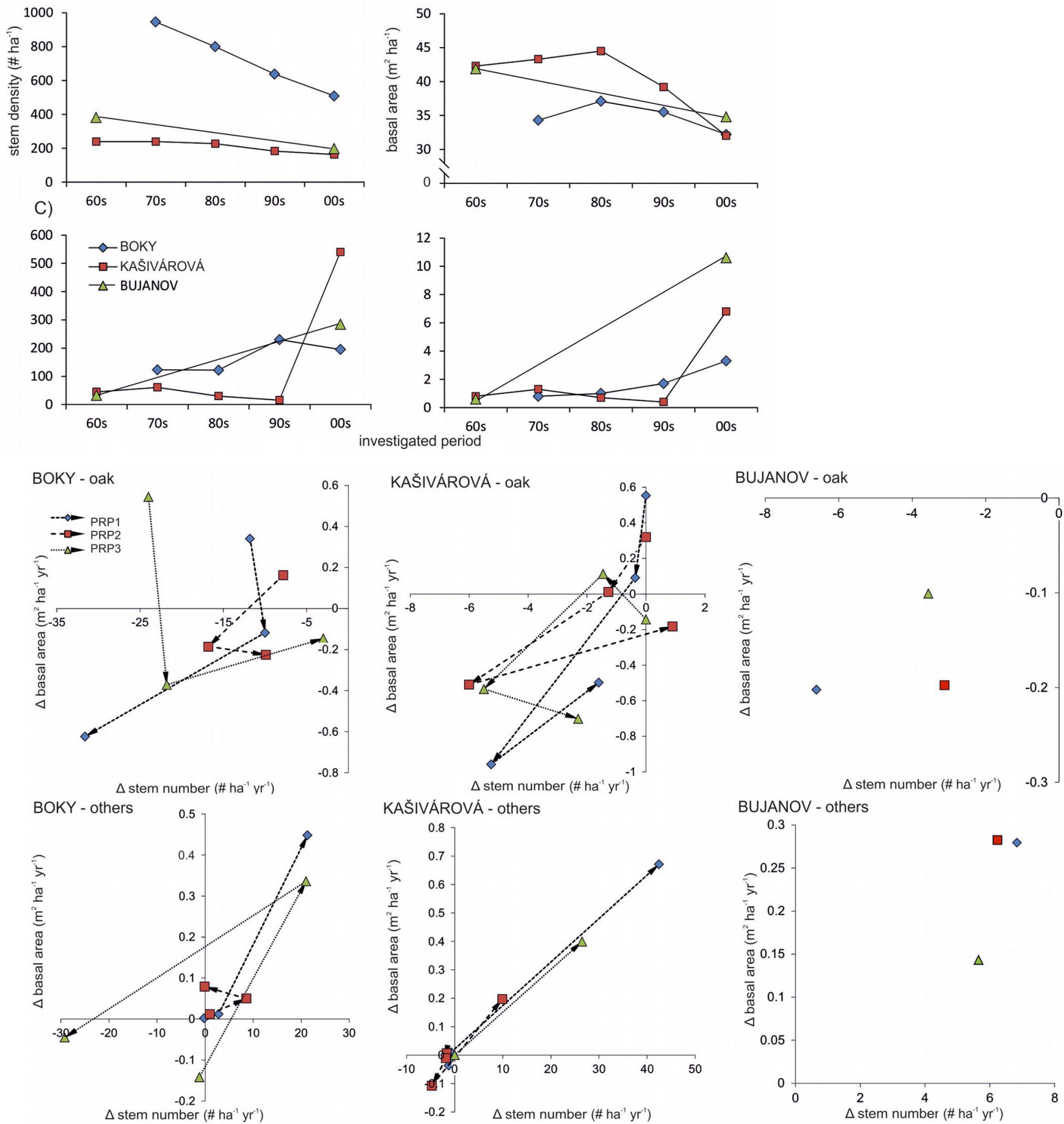

Fig. 2 - Annual changes $(\Delta)$ in the stem density and the basal area according to separate permanent research plots (PRP) and inventory cam paigns in the investigated forest reserves. Arrows indicate the temporal vector. 
gence towards the rotated-sigmoid distribution was observed in both reserves. Contrastingly, the diameter structure kept the rotated-sigmoid form in the old-growth forest Boky over all the investigated period. Nevertheless, we observed a significant reduction of lower tree layer density, which can be mainly accounted for by the mortality of oaks and their shift into higher dbh classes. In the Kašivárová reserve, the diameter structure significantly changed over time. Although the diameter distribution maintained a bimodal shape, hornbeam and beech density in the lower tree layer largely increased, which resulted in a typical rotated-sigmoid form in 2011 (Fig. 4). The diameter structure of oak shifted from a unimodal shape with almost all oak stems in the upper tree layer to a bimodal distribution with some oak recruitment appearing in the lower tree layer. The diameter structure in Bujanov changed markedly (Fig. 4). The unimodally distributed oak layer with emerging beech in the lower tree layer in 1966 shifted towards a distinctively bimodal distribution in 2009 . Currently, the stand is formed by oak in the upper tree layer and by beech in the middle and especially in the lower layer.

Structural shifts in species composition over the studied period disregarding the short-term (interdecadal) variation were calculated in the form of growth rates of stem density and basal area. Growth rates of oak were negative in all reserves, ranging from $-0.7 \% \mathrm{yr}^{-1}$ (Kašivárová) to $-2.1 \% \mathrm{yr}^{-1}$ (Bujanov) for stem density. The decrease of oak proportion in basal area was significantly less intensive and reached values between $-0.2 \% \mathrm{yr}^{-1}$ (Boky) and $-0.7 \% \mathrm{yr}^{-1}$ (Kašivárová). At the same time, in all investigated reserves we observed an increase of other tree species both in stem number (from $1.2 \% \mathrm{yr}^{-1}$ in Boky to $2.1 \% \mathrm{yr}^{-1}$ in Bujanov) and basal area (from $2.0 \% \mathrm{yr}^{-1}$ in Kašivárová to $2.5 \%$ $\mathrm{yr}^{-1}$ in Boky). Growth rates varied significantly among tree layers (Fig. 5). The most dynamic changes in oak tree number and basal area were found in the lower layer (Boky), lower and middle layer (Kašivárová) and middle layer (Bujanov). In Bujanov, oak lower layer was virtually absent.

The lower tree layer in Boky showed the highest oak mortality both in stem number $\left(-2.7 \% \mathrm{yr}^{-1}\right)$ and basal area $\left(-2.3 \% \mathrm{yr}^{-1}-\right.$ Fig. $5)$. Oak stem loss in the middle layer $(-0.8 \%$ $\left.\mathrm{yr}^{-1}\right)$ did not affect basal area, which exhibited even an imperceptible growth. In the upper layer, oak basal area increased by $0.5 \% \mathrm{yr}^{-1}$. Considering the dynamics of other species in the middle and the upper layer, we observed an increase of both stem number $\left(19.5 \% \mathrm{yr}^{-1}\right.$ and $20.2 \% \mathrm{yr}^{-1}$, respectively) and basal area $\left(27.5 \% \mathrm{yr}^{-1}\right.$ and $29.5 \% \mathrm{yr}^{-1}$, respectively).

An opposite situation was observed in Kašivárová (Fig. 5). The increase of oak
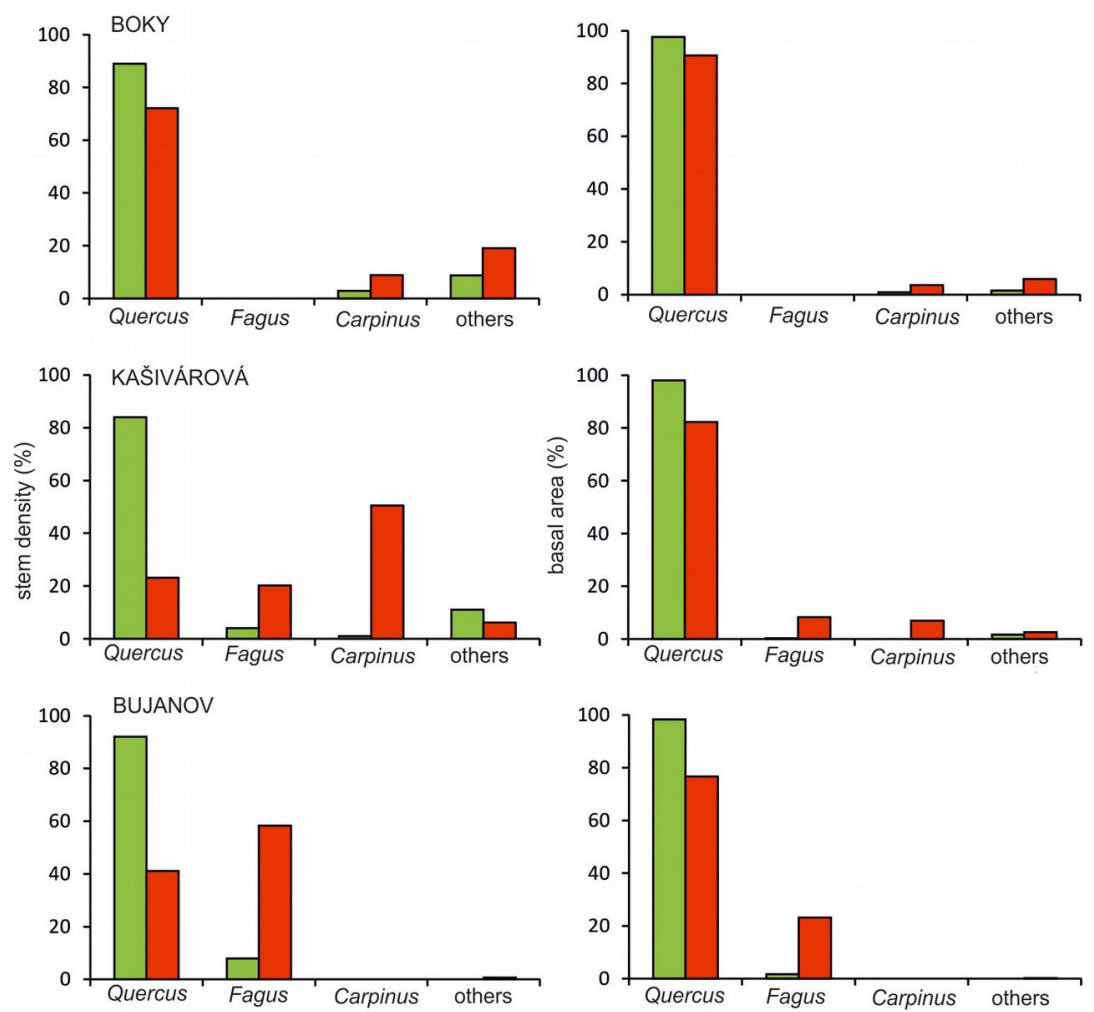

Fig. 3 - Tree species structure calculated from the stem density (left) and the basal area (right) in the investigated forest reserves for the first (green columns) and the last inventory campaign (red columns).
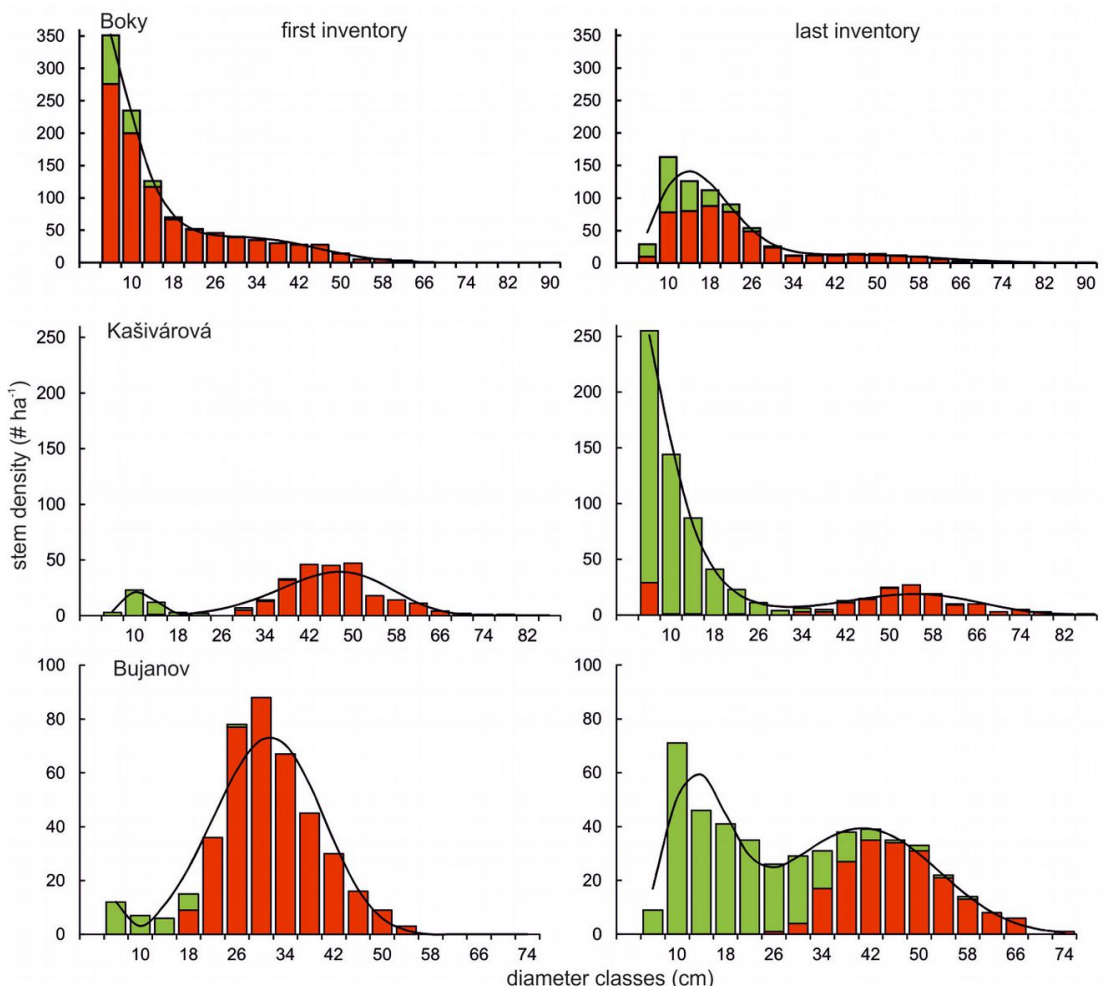

Fig. 4 - Empirical and fitted diameter distributions of the investigated oak-dominated forest reserves. Explanatory notes: red bars - oaks, green bars - other tree species, solid line - distri bution predicted by the finite mixture of two Weibull functions. Please note that tree individuals were grouped into $4 \mathrm{~cm}$ diameter classes. 


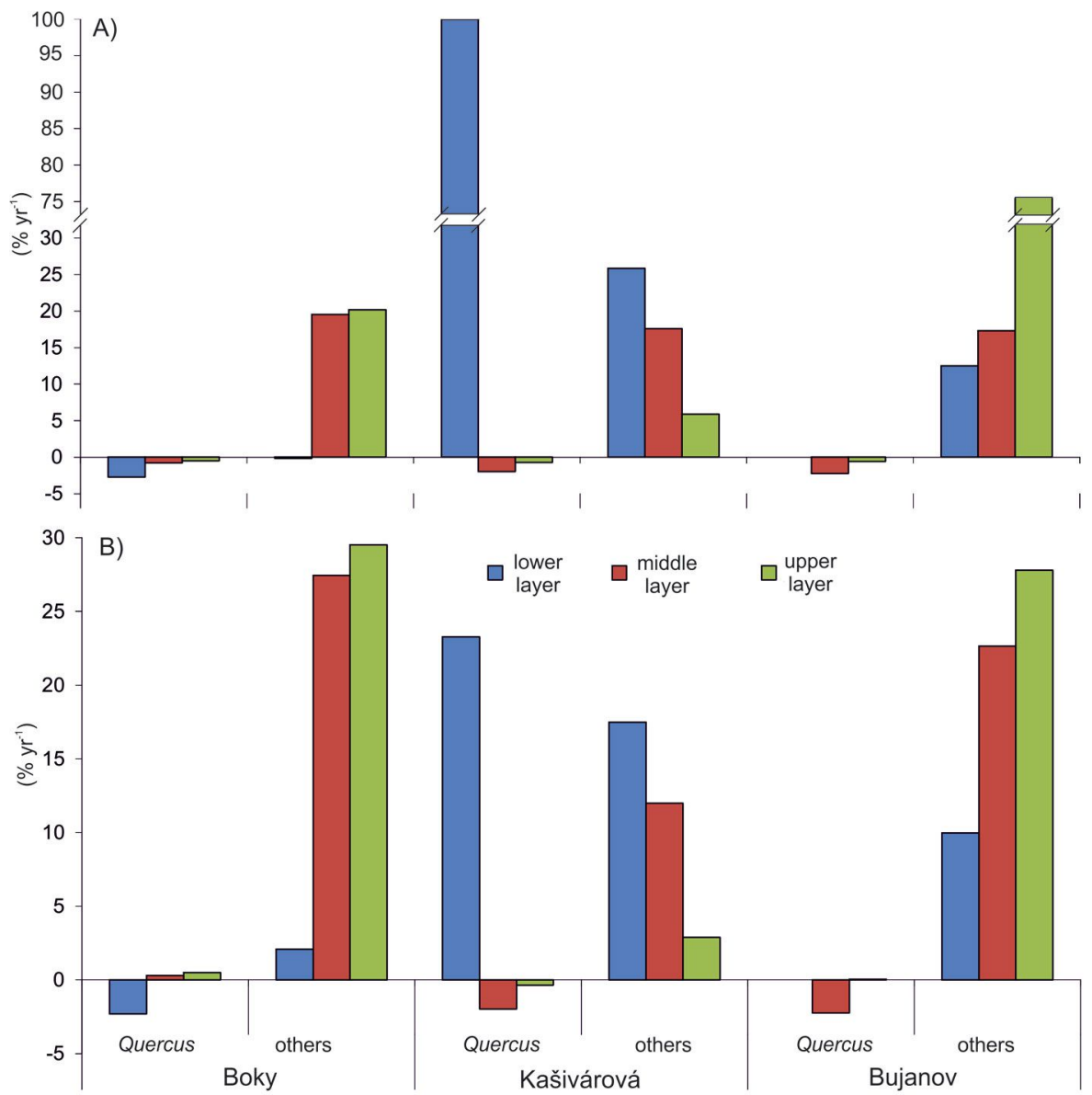

Fig. 5 - Growth rates of the stem density (A) and the basal area (B) according to respective tree layers and forest reserves, calculated using the eqn. 3 .

density in the lower layer by $100 \% \mathrm{yr}^{-1}$ was reflected also by growth of oak basal area $\left(23.3 \% \mathrm{yr}^{-1}\right)$. The overall decrease of oak was caused mainly by its reduction in the middle layer $\left(-2 \% \mathrm{yr}^{-1}\right.$ both by stem number and basal area) and to a lesser extent in the upper layer. Other tree species (beech and hornbeam) invaded especially the lower layer $\left(25.8 \% \mathrm{yr}^{-1}\right.$ and $17.5 \% \mathrm{yr}^{-1}$ by stem number and basal area, respectively) and the middle layer $\left(17.6 \% \mathrm{yr}^{-1}\right.$ and $12.0 \% \mathrm{yr}^{-1}$, respectively). Their growth rates in the upper layer were significantly lower and did not exceed $6 \% \mathrm{yr}^{-1}$ (stem density) and $3 \% \mathrm{yr}^{-1}$ (basal area).

The development in Bujanov showed several peculiar characteristics (Fig. 5). In the lower layer, the absence of oak individuals was closely associated with an extensive expansion of beech density by $12.5 \% \mathrm{yr}^{-1}$. In the middle layer, a massive increase of beech in stem number $\left(17.3 \% \mathrm{yr}^{-1}\right)$ and basal area $\left(22.6 \% \mathrm{yr}^{-1}\right)$ was accompanied by oak mortality $\left(-2.2 \% \mathrm{yr}^{-1}\right.$ both by stem number and basal area). The upper tree layer was characterized by a slight loss of mature oak density $\left(-0.6 \% \mathrm{yr}^{-1}\right)$; however, it was compensated by diameter growth of the remaining oaks $\left(0.05 \% \mathrm{yr}^{-1}\right.$ by basal area). Regarding the growth rates of beech, their highest values were recorded in the upper layer $\left(75.9 \% \mathrm{yr}^{-1}\right.$ and $27.8 \% \mathrm{yr}^{-1}$ by stem number and basal area, respectively).

\section{Discussion}

The results obtained in this study confirmed the expected decrease of oaks in all investigated areas, regardless of the intensity of past human impacts. This is consistent with the general decline of oaks observed in many European forests during the last decades (Oleksyn \& Przybyl 1987, Ragazzi et al. 1989, Führer 1998, Siwecki \& Ufnalski 1998, Thomas et al. 2002, Rohner et al. 2012). However, we discern some particularities regarding the oak loss according to the different levels of past human impact among the studied natural reserves.

Considering the spatial diversity, the recorded structures closely correspond with the relative intensity of past intervention on the investigated forests. This finding is in line with the conclusion of Clark \& Covey (2012) and Bauhus et al. (2009) on a negative effect of size-class exploitation on the persistence of old-growth attributes and structural diversity.

The most differentiated initial structure, ap- proximated by the rotated sigmoid function, was recorded in the reserve with no direct human intervention (Boky). The past-affected reserve in Kašivárová showed a bimodal pattern and the most affected Bujanov revealed even the typical unimodal distribution characteristic for even-aged forests (Pretzsch 2009). Accordingly, the more affected reserves reached higher values for the basic stand parameters, most likely due to a distinctive dominance of the upper layer. The average basal area and growing stock in Kašivárová and Bujanov (36.5-44 $\mathrm{m}^{2} \mathrm{ha}^{-1}$ and 284-518 $\mathrm{m}^{3} \mathrm{ha}^{-1}$, respectively) correlated negatively with their level of structural heterogeneity, while the stem number revealed a positive correlation.

The recorded amounts of deadwood are consistent with those reported for other oakdominated natural forests in Europe (Rahman et al. 2008, Petritan et al. 2012). Regardless of the historical background, we observed a continuous increase of deadwood volume and dead-to-live wood ratio in all the analyzed forests over 45 (or 30) years. Likewise, Vandekerkhove et al. (2009) described the slow long-term process of deadwood accumulation in oak-dominated, man-made forests left to self-development 10 to 150 years ago. Considering the dead-to-live wood ratio, the obtained values in this study were slightly lower than those reported for other oak-dominated natural forests. Rahman et al. (2008) presented dead-to-live wood ratios ranging from 30 to $40 \%$ depending on the forest associations, while Petritan et al. (2012) found a deadwood proportion of $23 \%$ in sessile oak-dominated plots.

Regarding the interdecadal variation of stand parameters, we did not recognize a persistent trend over the analyzed period. The common feature of all investigated forests was a gradual decline of basal area and growing stock since the 1980s. This trend closely corresponds with the epidemic of oak wilt (Ceratocystis fagacearum) in Slovakia and Hungary (Burkovský 1985, Leontovyc $\&$ Capek 1987). However, the only considerable difference was the rate of such decrease. A more distinctive decrease in all stand parameters was confirmed for the reserves which experienced a stronger past human impact. This is probably due to the fact that forests with artificially modified structure are more susceptible to pathogens than natural ecosystems (Führer 1998, Spiecker 2003). On the contrary, Brang et al. (2009) reported for forest reserves in Switzerland almost opposite trends typical of the earlyto mid-successional stages, namely an increase of basal area, growing stock and large trees density, as well as a decrease in stem number and species richness.

In this study several different patterns were revealed when the successional changes over the whole period of investigation were eva- 
luated. First of all, a clear tendency was observed toward differentiated, close-to-nature structure throughout the structural shift from the bimodal diameter distribution in both past-affected reserves. The bimodal diameter distribution described at the beginning of the investigation period in Kašivárová reached the typical rotated sigmoid patterns at the time of the last inventory. Similarly, the diameter structure in the Bujanov reserve after 40 years of unhindered recovery showed a transformation from unimodal to bimodal distribution. It is very likely that the recovery process in this reserve follows the same direction as observed in Kašivárová. The rotated sigmoid diameter distribution in Boky persisted during the entire investigation period. A similar trend was described by Westphal et al. (2006) and Kucbel et al. (2012) in beech virgin forests in Europe. We have observed a tendency to the displacement of light-demanding oak by shade-tolerant species (beech, hornbeam). The intensity of such substitution directly reflected the intensity of the local structure modification in the past. Among the stand parameters considered, stem number showed the most distinctive change, while changes in tree species composition by basal area and growing stock were not so apparent yet.

In the Boky reserve, distinctive structural changes occurred within the lower and middle layer. A significant loss of oaks from the lower layer stems from a discontinuous oak recruitment in this site. The dieback of oaks resulted in an increase of stem number of hornbeam and other tree species. A continuous accumulation of deadwood in this site across all the investigated decades is directly linked to tree mortality. From the point of view of ecosystem stability, the loss of oak individuals is constantly counterbalanced by the ingrowth of accompanying tree species, e.g., hornbeam and field maple (Korpel 1995). In Kašivárová, oak abundance increased only in the lower layer. In spite of this fact, a decrease of oak proportion in the lower layer was observed as the result of the massive hornbeam expansion occurring periodically, and is a natural part of developmental cycle of natural oak forests (Korpel 1995). The real loss of oak individuals in this reserve was recorded in the middle and upper layers as a result of oak wilt, which occurred throughout Slovak forests in the 1980s (Burkovský 1985). This is supported by a noticeable local increase of deadwood volume after the inventory in the 1990s (Saniga \& Schütz 2002, Saniga 2005). Oak mortality favored a rapid natural regeneration of shade-tolerant beech in the lower layer and its growth into the middle layer. The most intensive change in tree species composition was observed in the Bujanoy reserve. The absence of oaks in the lower tree layer and the dieback of oaks in the middle layer (outcompeted by beech) led towards a complex change of the spatial structure. A closed beech canopy in the lower layer hampers the natural regeneration of oaks. According to von Lüpke (1998), successful regeneration of oaks occurs when the light availability does not fall below $15-20 \%$ of the full light, and at least $30-60 \%$ is required after two years. In the current situation, a successional transition from the dominance of oaks towards a closed canopy dominated by shade-tolerant beech is expected.

The vertical stand structure seems to drive the recovery process. In almost all cases, oak showed negative growth rates, while other tree species revealed rather positive growth rates in all tree layers of the investigated forests. The scarse initial abundance of the other tree species at the time of the first inventory may be the reason of the distinctive positive growth rates of such species in the Boky reserve. Moreover, a clear association between the intensity of past human impact and the outgrowing of the lower tree layer was recognized, suggesting that outgrowing of the natural regeneration is crucial for the recovery process. In addition to the competitive exclusion observed in the lower layer in Boky, we recognized a massive recruitment of other species to the lower layer in both past-affected reserves. Furthermore, successful regeneration of oak was recorded only in reserves with no or moderate level of past human impact (Boky, Kašivárová).

The successional shift toward the dominance of shade-tolerant species is expected based on the disturbance theory. However, our results are in agreement with the findings by Matuszkiewicz (1977), Jakubowska-Gabara (1996) or Hédl et al. (2010), who report the replacement of oak-dominated thermophilous forest by mesic communities after the cessation of human intervention. Our study showed that the oak decline could be mostly a consequence of the recovery after the past third-party intervention rather than the effect of environmental changes. Regardless of the altered natural conditions, our results strongly support the hypothesis that the process of forest recovery and oak loss significantly depends on the intensity of past human impact. However, altered environmental conditions should be still considered an important factor lowering the resilience of past-affected ecosystems (Bréda et al. 2006, Lindner et al. 2010, Rigling et al. 2013).

\section{Acknowledgements}

This study was supported by the Slovak Research and Development Agency, project APVV-0286-10. The authors would like to thank the anonymous reviewers for their helpful comments and suggestions on earlier version of the manuscript.

\section{References}

Bauhus J, Puettmann K, Messier C (2009). Silviculture for old-growth attributes. Forest Ecology and Management 258 (4): 525-537. - doi: 10.10 16/j.foreco.2009.01.053

Birks HJB (2005). Mind the gap: how open were European primeval forests? Trends in Ecology and Evolution 20: 154-156. - doi: 10.1016/j. tree.2005.02.001

Blattný T, Štastný T (1959). Prirodzené rozšírenie lesných drevín na Slovensku [Natural distribution of forest tree species in Slovakia]. SVPL, Bratislava, Slovakia, pp. 402. [in Slovak]

Bohn U, Neuhäusl R (2000). Karte der natürlichen Vegetation Europas [Map of the Natural Vegetation of Europe]. Bundesamt für Naturschutz, Bonn, Germany, pp. 11. [in German]

Brang P, Hallenbarter D, Rohrer L, Commarmot B, Heiri C, Bugmann H (2009). Insights from 50 years of research in natural forest dynamics in Switzerland. In: Proceedings of the " $4^{\text {th }}$ Symposium of the Hohe Tauern National Park Conference. Volume for Research in Protected Areas". Castle of Kaprun (Austria) 17-19 September 2009. Hohe Tauern National Park Council, Matrei in Osttirol, Austria, pp. 41-44.

Brang P, Heiri C, Bugmann H (2011). Waldreservate. 50 Jahre natürliche Waldentwicklung in der Schweiz [Forest reserves. 50 years of the natural succession in the Switzerland]. Haupt, Bern, Switzerland, pp. 272. [in German].

Bréda N, Huc R, Granier A, Dreyer E (2006). Temperate forest trees and stands under severe drought: a review of ecophysiological responses, adaptation processes and long-term consequences. Annals of Forest Science 63: 625-644. - doi: 10.1051/forest:2006042

Burkovský J (1985). Viac pozornosti hromadnému hynutiu dubov $\mathrm{v}$ chránených územiach [More attention for the natural oak decline]. Pamiatky prírody 1: 26-27. [in Slovak]

Bücking W (2003). Are there threshold numbers for protected forests? Journal of Environmental Management 67 (1): 37-45. - doi: 10.1016/S030 1-4797(02)00186-X

Clark JA, Covey KR (2012). Tree species richness and the logging of natural forests: a meta-analysis. Forest Ecology and Management 276: 146153. - doi: 10.1016/j.foreco.2012.04.001

Connell JH (1978). Diversity in tropical rain forests and coral reefs. Science 199 (4335): 1302-1310. - doi: 10.1126/science.199.4335.13 02

Cowell CM, Hoalst-Pullen N, Jackson MT (2010). The limited role of canopy gaps in the successional dynamics of a mature mixed Quercus forest remnant. Journal of Vegetation Science 21: 201-212. - doi: 10.1111/j.1654-1103.2009. 01137.x

Führer E (1998). Oak decline in central Europe: a synopsis of hypotheses. In: "Population Dynamics, Impacts, and Integrated Management of Forest Defoliating Insects" (McManus ML, Liebhold AM eds). General Technical Report NE247, USDA Forest Service, pp. 7-24. [online] URL: http://iufro-archive.boku.ac.at/wu70307/ 
banska/fuhrer.PDF

Halamová M, Saniga M (2006). Structure, production and regeneration processes in the oak primeval forest in the National Nature Reserve Boky. Folia Oecologica 33: 13-26. [online] URL: http://agris.fao.org/agris-search/search.do? recordID=SK2009000003

Hartmann G, Blank R, Lewark S (1989). Eichensterben in Norddeutschland - Verbreitung, Schadbilder, moegliche Ursachen [Oak decline in northern Germany - extent, examples, possible causes]. Forst \& Holz 44: 475-487. [in German] Hill MO, Roy DB, Thompson K (2002). Hemeroby, urbanity and ruderality: bioindicators of disturbance and human impact. Journal of Applied Ecology 39: 708-720. - doi: 10.1046/j.1365-26 64.2002.00746.x

Humenanský S (1990). Lesnícky inventarizačný výskum v S̆PR Bujanov [Forestry inventory in NNR Bujanov]. ŠOP, Prešov, Slovakia, pp. 7. [in Slovak]

Hédl R, Kopecký M, Komárek J (2010). Half a century of succession in a temperate oakwood: from species-rich community to mesic forest. Diversity Distribution 16: 267-276. - doi: 10.1111/ j.1472-4642.2010.00637.x

Jakubowska-Gabara J (1996). Decline of Potentillo albae-Quercetum Libb. 1933 phytocoenoses in Poland. Vegetatio 124: 45-59. - doi: 10.1007/ BF00045143

Jarolímek I, Šibík J (2008). Diagnostic, constant and dominant species of the higher vegetation units of Slovakia. Veda, Bratislava, Slovakia, pp. 332 .

Josefsson T, Hörnberg G, Östlund L (2009). Longterm human impact and vegetation changes in a boreal forest reserve: implications for the use of protected areas as ecological references. Ecosystems 12: 1017-1036. - doi: 10.1007/s10021-0099276-y

Kavuljak A (1942). Dejiny lesníctva a drevárstva na Slovensku [History of the forestry and timber industry in Slovakia]. Veda, Martin, Slovakia. [in Slovak]

Korpel S (1989). Pralesy Slovenska [Slovak primeval forests]. Veda, Bratislava, Slovakia, pp. 332. [in Slovak]

Korpel S (1995). Die Urwälder der Westkarpaten [Virgin forests in western Carpathians]. Gustav Fischer Verlag, Stuttgart, Germany, pp. 310. [in German]

Kucbel S, Saniga M, Jaloviar P, Vencúrik J (2012). Stand structure and temporal variability in old-growth beech-dominated forests of the northwestern Carpathians: a 40-years perspective. Forest Ecology and Management 264: 125 123. - doi: 10.1016/j.foreco.2011.10.011

Leibundgut H (1993). Europäische Urwälder. Wegweiser zur naturnahen Waldwirtschaft [European virgin forests. A guide to close-tonature forest management]. Haupt, Bern, Stuttgart, Wien, pp. 260. [in German]

Leontovyc R, Capek M (1987). Eichenwelken in der Slowakei [Oak decline in Slovakia]. Österreichische Forstrzeitschrift 98: 51-52. [in German]
Lindner M, Maroschek M, Netherer S, Kremer A, Barbati A, Garcia-Gonzalo J, Seidl R, Delzon S, Corona P, Kolström M, Lexer MJ, Marchetti M (2010). Climate change impacts, adaptive capacity, and vulnerability of European forest ecosystems. Forest Ecology and Management 259: 698709. - doi: 10.1016/j.foreco.2009.09.023

Macdonald P, Du J (2010). mixdist: finite mixture distribution models. $\mathrm{R}$ package version 0. 5-3. [online] URL: http://CRAN.R-project.org/package $=$ mixdist

Matuszkiewicz A (1977). Der thermophile eichenwald in NO-Polen als anthropozoogene Gesellschaft [The thermophile oak forest in NE Poland as the anthropic community]. In: "Vegetation und Fauna" (Tüxen R, Cramer J eds). Berichte der Internationalen Symposien der Internationalen Verein für Vegatationskunde, Vaduz, Liechtenstein, pp. 527-540. [in German]

Oleksyn J, Przybyl K (1987). Oak decline in the Soviet Union - scale and hypotheses. European Journal of Forest Pathology 17: 321-336. - doi: 10.1111/j.1439-0329.1987.tb01325.x

Oliver CD, Larson BC (1996). Forest stand dynamics. Wiley, New York, USA, pp. 520.

Parviainen J, Little D, O'Sullivan A, Kettunen M, Korhonen M (1999). Research in forest reserves and natural forests in European countries. EFI Proceedings No 16. European Forest Institute, Joensuu, Finland, pp. 304

Petritan AM, Biris I A, Merce O, Turcu DO, Petri$\tan$ IC (2012). Structure and diversity of a natural temperate sessile oak (Quercus petraea L.) European beech (Fagus sylvatica L.) forest. Forest Ecology and Management 280: 140-149. doi: 10.1016/j.foreco.2012.06.007

Petráš R, Pajtík J (1991). Sústava česko-slovenských objemových tabuliek dreva [Czechoslovak tables of timber volumes]. Lesnícky časopis 37 : 49-56. [in Slovak]

Pretzsch H (2009). Forest dynamics, growth an yield: from measurement to model. SpringerVerlag, Freising, Germany, pp. 670.

R Development Core Team (2010). R: A language and environment for statistical computing. $\mathrm{R}$ Foundation for Statistical Computing, Vienna, Austria. [online] URL: http://www.R-project.org Ragazzi A, Dellavalle-Fedi I, Mesturino L (1989). The oak decline: a new problem in Italy. European Journal of Forest Pathology 19: 105-110. doi: 10.1111/j.1439-0329.1989.tb00240.x

Rahman MM, Frank G, Ruprecht H, Vacik H (2008). Structure of coarse woody debris in Lange-Leitn Natural Forest Reserve, Austria. Journal of Forest Science 54: 161-169.

Rigling A, Bigler Ch, Eilmann B, FeldmeyerChriste E, Gimmi U, Ginzler Ch, Graf U, Mayer P, Vacchiano G, Weber P, Wohlgemuth T, Zweifel R, Dobbertin M (2013). Driving factors of a vegetation shift from Scots pine to pubescent oak in dry Alpine forests. Global Change Biology 19: 229-240. - doi: 10.1111/gcb.12038

Rohner B, Bigler Ch, Wunder J, Brang P, Bugmann $H$ (2012). Fifty years of natural succession in Swiss forest reserves: changes in stand structure and mortality rates of oak and beech. Jour- nal of Vegetation Science 23: 892-905. - doi: 10.1111/j.1654-1103.2012.01408.x

Saniga M, Schütz JPH (2002). Relation of dead wood course within the development cycle of selected virgin forests in Slovakia. Journal of Forest Science 48: 513-528.

Saniga M (2005). Štruktúra a regeneračné procesy dubového pralesa v NPR Kašivárová [Structure and regeneration of oak old-growth forest in NNR Kašivárová]. Ochrana prírody 24: 21-33. [in Slovak]

Schuck A, Parviainen J, Bücking W (1994). A review of approaches to forestry research on structure, succession and biodiversity of undisturbed and semi-natural forests and woodlands in Europe. Working paper 3, European Forest Institute, Joensuu, Finland, pp. 64.

Siwecki R, Liese W (1991). Oak decline in Europe. In: Proceedings of the International Symposium "Oak decline in Europe". Kornik (Poland) 15-18 May 1990. Polish Academy of Sciences, Kornik, Poland, pp. 360.

Siwecki R, Ufnalski K (1998). Review of oak stand decline with special reference to the role of drought in Poland. European Journal of Forest Pathology 28: 99-112. - doi: 10.1111/j.1439-032 9.1998.tb01171.x

Smejkal GM, Bindiu C, Visoiu-Smejkal D (1995). Banater Urwälder [Virgin forests of Banater]. Verlag Mirton, Temesvar, Romania, pp. 198. [in German]

Smelko S (2000). Dendrometria [Dendrometry]. Vydavatelstvo Technickej University, Zvolen, Slovakia, pp. 399. [in Slovak]

Spiecker H (2003). Silvicultural management in maintaining biodiversity and resistance of forests in Europe - temperate zone. Journal of Environmental Management 67: 55-65. - doi: 10.1016/S 0301-4797(02)00188-3

Taylor AH, Jinyan H, ShiQiang Z (2004). Canopy tree development and undergrowth bamboo dynamics in old-growth Abies-Betula forests in southwestern China: a 12-year study. Forest Ecology and Management 200: 347-360. - doi: 10.1016/j.foreco.2004.07.007

Thomas FM, Blank R, Hartmann G (2002). Abiotic and biotic factors and their interactions as causes of oak decline in Central Europe. Forest Pathology 32: 277-307. - doi: 10.1046/j.14390329.2002.00291.x

Tomaštík J, Saniga M (2011). Štruktúra a velkost porastových medzier v NPR Bujanovská dubina [Structure and the gap size in NNR Bujanovská dubina]. Acta Facultatis Forestalis Zvolen 53 (2): 19-28. [in Slovak]

Vandekerkhove K, De Keersmaeker L, Menke N, Meyer P, Verschelde P (2009). When nature takes over from man: dead wood accumulation in previously managed oak and beech woodlands in north-western and central Europe. Forest Ecology and Management 258: 425-435. - doi: $10.1016 /$ j.foreco.2009.01.055

Vera FWM (2000). Grazing ecology and forest history. CABI, Wallingford, USA, pp. 506.

von Lüpke B (1998). Silvicultural methods of oak regeneration with special respect to shade tole- 
rant mixed species. Forest Ecology and Management 106: 19-26. - doi: 10.1016/S0378-1127(97) 00235-1

Watt AS (1925). On the ecology of British beechwoods with special reference to their regeneration. Part II. The development and structure of beech communities on the Sussex Downs. Journal of Ecology 13: 27-73. - doi: 10.2307/22555 56

Westphal C, Tremer N, von Oheimb G, Hansen J, von Gadow K, Härdtle W (2006). Is the reverse J-shaped diameter distribution universally applicable in European virgin beech forests? Forest Ecology and Management 223: 75-83. - doi: 10. 1016/j.foreco.2005.10.057

White PS, Pickett STA (1985). Natural disturbance and patch dynamics, an introduction. In: "The ecology of natural disturbance and patch dynamics" (Pickett STA, White PS eds). Academic Press, New York, USA, pp. 3-13.
Whitmore TC (1975). Tropical rain forests of the Far East. Clarenden Press, Oxford, UK, pp. 368. Zhang L, Gove JH, Liu C, Leak WB (2001). A finite mixture of two Weibull distributions for modelling the diameter distributions of rotatedsigmoid, uneven-aged stands. Canadian Journal of Forest Research 31: 1654-1659. - doi: 10.1139/x01-086 